\title{
The public returns to public educational investments in African-American males
}

\author{
Henry M. Levin ${ }^{\mathrm{a}, *}$, Clive Belfield $^{\mathrm{b}}$, Peter Muennig ${ }^{\mathrm{c}}$, Cecilia Rouse $^{\mathrm{d}}$

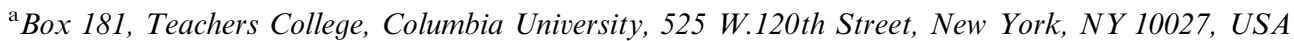 \\ ${ }^{\mathrm{b}}$ Department of Economics, Queens College, City University of New York, 65-30 Kissena Blvd, Flushing, NY 11367, USA \\ ${ }^{\mathrm{c}}$ Mailman School of Public Health, Columbia University, 600 W.168th Street, New York, NY 10032, USA \\ ${ }^{\mathrm{d}}$ Education Research Section, Firestone Library, Princeton University, Princeton, NJ 08544, USA
}

\begin{abstract}
This paper calculates the public savings (financial benefits) from greater public investments in the education of AfricanAmerican males. Over one-fifth of each age cohort of black males in US is not a high school graduate. We identify five interventions that would - based on credible research — increase the graduation rate; we also report the public cost of each intervention. We then calculate the lifetime public benefits in terms of increased tax revenues and lower spending on health and crime. In present values, for a black male aged 20 , these public benefits amount to $\$ 256,700$ per new graduate and the median intervention would cost only $\$ 90,700$. The benefit/cost ratio is 2.83 . Simply equating the high school graduation rate of black males with that of white males would yield public savings of $\$ 3.98$ billion for each age cohort. These results suggest that increased investments in education for black males at risk of dropping out of high school should be an economic priority.
\end{abstract}

(C) 2007 Elsevier Ltd. All rights reserved.

JEL classification: $\mathrm{I} 2 ; \mathrm{H} 5$

Keywords: Costs; Rate of return; Resource allocation

\section{Introduction}

Among all the major demographic groups in US, African-American (black) males experience the poorest educational outcomes. ${ }^{1}$ Whether measuring such outcomes in terms of test scores, high school graduation, post-secondary attendance, or college graduation, African-American males lag substan-

\footnotetext{
*Corresponding author.

E-mail address: levin@tc.edu (H.M. Levin).

${ }^{1}$ For brevity, we use "black" and "African-American" interchangeably; "graduation" refers to high school.
}

tially behind other groups. It is widely recognized that unequal educational outcomes lead to unequal economic consequences throughout the life course. In particular, individuals with low attainment and poor quality education - these often overlap - can expect to face inferior employment prospects, low wages, poor health, and greater involvement in the criminal justice system.

At its heart, such educational inequality for black males is a moral issue; a challenge to fairness or justice in a society in which education is the major public instrument for "leveling the playing field". But it is also an economic issue; poor education 
leads to large social costs in the form of lower societal income and economic growth, lower tax revenues, and higher costs of such public services as health, criminal justice, and public assistance. Thus, it is possible to assess efforts to improve educational outcomes for black males as a public investment which might yield high returns.

In this article, we undertake a comprehensive assessment of the public returns to investments for improving educational attainments of black males. We begin by documenting the extent of educational inequality between blacks and whites. Next, we identify educational interventions which would increase the rate of high school graduation and we calculate their public costs. Then, we summarize the public benefits of increasing the numbers of black male high school graduates in terms of higher tax revenues, reduced public costs for health services, and reduced costs of criminal justice services. Finally, we will combine these data into estimating net present values and benefit-cost analyzes. We show that it is in the economic interest of society to invest more in the education of these individuals.

\section{Educational status of black males}

The relative educational status of black males in US is stark. The disparities are evident across many educational metrics. In a thorough analysis of black-white skills gaps, Neal (2006) reports significant differences in attainment (and graduation rates). In 2000, black males aged 26-30 had on average 0.72 fewer years of education than white males (the gap for females was 0.62). This gap was closing from the 1950-60s, but it appears to have stalled since 1990s. Test scores show a similar pattern - the black-white gap fell sharply for both reading and math during the 1980 s, but stabilized thereafter; the 2004 gap is almost exactly the same as the 1996 gap. $^{2}$ Also, black males are disproportionately in special education and suspended or expelled from school (Holzman, 2006). Finally, these schooling differences affect college attainment $-42 \%$ of whites aged $18-24$ are enrolled in college, compared to $32 \%$ of blacks; black males also complete college at lower rates (NCES, 2005, Table 184).

\footnotetext{
${ }^{2}$ In 1978, male white/black NAEP math scores were 306/268, a 38-point gap. By 1986, the gap was 29 points, and from 1996 to 2004 , it remained at 28 points. NAEP reading results show the same pattern.
}

Table 1

Highest level of educational attainment for those aged 20

\begin{tabular}{lllll}
\hline & \multicolumn{2}{l}{ Black males } & \multicolumn{2}{l}{ White males } \\
\hline Less than ninth grade & 6000 & $2 \%$ & 18,000 & $1 \%$ \\
High school dropout & 67,000 & $22 \%$ & 193,000 & $14 \%$ \\
High school graduate & 99,000 & $33 \%$ & 402,000 & $29 \%$ \\
Some college or above & 133,000 & $44 \%$ & 757,000 & $56 \%$ \\
Total cohort size & 305,000 & & $1,369,000$ & \\
\hline
\end{tabular}

Source: Current Population Survey, March 2005.

Notes: Race-specific adjustments are made for institutionalization and GED receipt.

Importantly, these outcome differences do not fully capture differences in education investment because they do not account for school quality or college quality. Generally, schooling resources that black children receive are inferior to those of white children (Duncombe \& Yinger, 2005); and black high school graduates are more likely to attend 2-year colleges rather than 4-year colleges which have larger state subventions (NCES, 2005). ${ }^{3}$ Based on data from the Education Trust (2006), in over half of all states, government funding in highminority school districts is less than in low-minority districts. ${ }^{4}$ Across the US, the average shortfall is \$900-1200 per year. Therefore, as an approximation, total public $\mathrm{K}-12$ educational investment per black student is $\$ 20,000$ less than per white student. ${ }^{5}$ Of course, this disparity is understated by the amount of further or compensatory expenditure that is needed to equalize educational outcomes of children from disadvantaged families.

We focus on attainment and high school graduation. We select this measure because graduation captures both cognitive and non-cognitive attributes that are important for success in adulthood. It is usually a minimum requirement for further training and higher education and it opens up a range of future possibilities. Table 1 shows attainment levels

\footnotetext{
${ }^{3}$ Private family educational investments are also likely to be lower for black children - only $33 \%$ of young black children live in two-parent homes; the respective figure for white children is 79\% (Neal, 2006, Table 11); other disparities across families are reported in Jencks and Phillips (1998).

${ }^{4}$ This is so for several reasons. Funds are not in practice allocated using equity-driven formulae. Title I includes a factor explicitly allocating more funds to high-spending states. Little information exists on where resources actually flow at the student level. Spending on teachers is higher in wealthier districts.

${ }^{5}$ The calculation is $\$ 1000$ per K-12 year plus the cost of 0.8 years of schooling at $\$ 8500$ per year.
} 
by race/ethnicity for those aged 20 (allowing for those who graduate late). ${ }^{6}$ Of the black male population, $22 \%$ are high school dropouts; the corresponding figure for white males is $14 \%$. College progression rates are lower for black males also. To equalize black and white graduation rates would require an additional 24,000 black male graduates each year. In the following, we calculate the economic consequences of failing to ensure graduation per black male student and for the aggregate situation where black male graduation rates are lower than white male rates.

\section{Increasing high school graduation for black males}

To identify effective interventions for increasing high school graduation rates for black males, we undertook a wide literature search. ${ }^{7}$ Of the hundreds of articles and reports we retrieved, very few met the criteria of demonstrating interventions that raised graduation rates on the basis of rigorous and systematic evaluation. Only five studies met our criteria of using a credible evaluation design and yielding improvements in graduation rates. ${ }^{8}$ The interventions in these studies are summarized in Table 2.

Two of the selected interventions take place at pre-school. The Perry Preschool Program (PPP) is a high quality pre-school program that was the focus of an experimental study using random assignment in the 1960 s in which participants and nonparticipants were followed-up to age 40 (Belfield et al., 2006). The Chicago child-parent centers (CPC) was established in 1967 to provide early education and family-support services emphasizing

\footnotetext{
${ }^{6}$ We use Current Population Survey (CPS) data accounting for two ways in which the CPS is less than ideal. First, we adjust for persons who are incarcerated-these are not counted in the CPS - using incarceration rate data by education level from Raphael (2004). Second, we adjust for GED receipt, which is not equivalent to a high school diploma, using data from the NELS derived by Rumberger (2004).

${ }^{7}$ This included searches of journal articles, search engines and Columbia University libraries. Special scrutiny was given to reports from three organizations with substantial experience in educational evaluations: Manpower Development Research Corporation, the Rand Corporation, and Mathematica Policy Research (we appreciate the assistance of Fred Doolittle at MDRC and Mark Dynarski at MPR).

${ }^{8} \mathrm{We}$ were especially interested in studies using experimental or quasi-experimental methods or strong econometric identification strategy. In some cases, the evaluations of interventions were of very poor quality. In other cases, the evaluations suggested that there was little educational impact.
}

math and reading skills and using high staff-student ratios and parental education. The evaluation used a quasi-experimental design to compare the performance of CPC participants with a matched control group of non-participants; members of both groups were followed-up to age 20 (Reynolds et al., 2002).

Class size reduction (CSR) is based upon the Tennessee Project Star experimental study in which students were randomly assigned to larger classes (22 students) or smaller ones (15 students) for up to 4 years from kindergarten to third grade (Finn et al., 2005). The teacher salary increase (TSR) study focused on the effects of raising teacher salaries on graduation rates using state data with a 10 year time lag assumed before the increased graduation rates would show (Loeb \& Page, 2000). The underlying assumption of this study is that higher teacher salaries will attract more qualified and effective teachers to replace those who leave, and this will raise graduation rates. Finally, First Thing First (FTF) is a high school reform; it reflects closely the present wave of urban, high school reform with its emphasis on small learning communities, instructional improvement, and teacher advocacy for each student (Quint, Bloom, Rebeck Black, Stephens, \& Akey, 2005). The research design was a discontinuous time-series on data from the site that has accumulated the most extensive FTF experience, Kansas City, KS.

Each intervention showed positive impacts on graduation rates. Column 3 of Table 2 shows the estimated new high school graduates if the intervention was delivered to 100 students. The educational effectiveness is based upon the evaluations of each of the reforms: PPP is the most effective at 19 new graduates; TSI would yield five new graduates. ${ }^{9}$ All interventions are replicable, and although none are limited only to black males, all but the TSI address predominantly black students. ${ }^{10}$ Thus, we

\footnotetext{
${ }^{9}$ Since they occur at different educational levels, these interventions may be combined to strengthen the effects. For example, it appears that the impact of CSI on student achievement is greater, the higher the salary of teachers. Presumably, higher quality teachers associated with higher salaries are able to use smaller class size more productively (see Peevely, Hedges, \& Nye, 2005).

${ }^{10}$ In PPP and CPC, almost all participants were black. In CSR, we use graduation rates for students on free lunch, populations with a high concentration of blacks in the experimental setting. For FTF, about half of the students were black. For TSI, the data are based upon state averages and may understate the expected improvement in graduation rates for black males because of their relatively small number in the overall student population (about
} 
Table 2

Interventions that demonstrably raise the high school graduation rate

\begin{tabular}{|c|c|c|c|c|c|}
\hline Intervention & Details of the intervention & $\begin{array}{l}\text { Extra high school } \\
\text { graduates if } \\
\text { intervention is given } \\
\text { to } 100 \text { students }\end{array}$ & $\begin{array}{l}\text { Program } \\
\text { costs per } \\
\text { student } \\
(\$)^{\mathrm{a}}\end{array}$ & $\begin{array}{l}\text { Program costs } \\
\text { per new high } \\
\text { school } \\
\text { graduate }(\$)^{\mathrm{b}}\end{array}$ & $\begin{array}{l}\text { Total educational } \\
\text { costs per new } \\
\text { high school } \\
\text { graduate }(\$)^{\mathrm{c}}\end{array}$ \\
\hline $\begin{array}{l}\text { PPP (Perry } \\
\text { Pre-school } \\
\text { Program) }\end{array}$ & $\begin{array}{l}1.8 \text { years of a center-based program for } \\
2.5 \mathrm{~h} \text { per weekday, child:teacher ratio of } \\
5: 1 \text {; home visits; and group meetings of } \\
\text { parents }\end{array}$ & 19 & 12,532 & 65,959 & 90,694 \\
\hline $\begin{array}{l}\text { CSR (class } \\
\text { size } \\
\text { reduction) }\end{array}$ & $\begin{array}{l}\text { Four years of schooling (grades } \mathrm{K}-3 \text { ) with } \\
\text { class size reduced from } 25 \text { to } 15 \text {. }\end{array}$ & 18 & 13,075 & 72,638 & 97,373 \\
\hline $\begin{array}{l}\text { FTF (First } \\
\text { Things First) }\end{array}$ & $\begin{array}{l}\text { Comprehensive school reform of small } \\
\text { learning communities with dedicated } \\
\text { teachers, family advocates, and } \\
\text { instructional improvement efforts }\end{array}$ & 16 & 5493 & 34,331 & 59,066 \\
\hline $\begin{array}{l}\text { CPC } \\
\text { (Chicago } \\
\text { child-parent } \\
\text { center } \\
\text { program) }\end{array}$ & $\begin{array}{l}\text { Center-based pre-school program: } \\
\text { parental involvement, outreach and } \\
\text { health/nutrition services. Based in public } \\
\text { schools }\end{array}$ & 11 & 4728 & 42,979 & 67,714 \\
\hline $\begin{array}{l}\text { TSI (teacher } \\
\text { salary } \\
\text { increase) }\end{array}$ & $\begin{array}{l}10 \% \text { increase in teacher salaries for all } \\
\text { years } \mathrm{K}-12\end{array}$ & 5 & 2865 & 95,503 & 120,238 \\
\hline
\end{tabular}

Sources: PPP—Belfield, Nores, Barnett, and Schweinhart (2006); CSR_Finn, Gerber, and Boyd-Zaharias (2005); FTF-Quint (2005); CPC - Reynolds, Temple, Robertson, and Mann (2002); TSI-Loeb and Page (2000). Costs are expressed in present values at age 20 using a $3.5 \%$ discount rate.

${ }^{\mathrm{a}}$ Cost per student counts the costs of delivering the intervention.

${ }^{\mathrm{b}}$ Cost per new high school graduate counts the costs of delivering the intervention to 100 students.

${ }^{\mathrm{c}}$ Total costs are program costs plus the induced costs from extra attainment in high school and college $(\$ 24,735)$.

have reasonable grounds for expecting similar effects if the interventions were implemented today.

We now turn to the public costs of these interventions. Costs were taken from studies that accounted directly for the resources and their prices for each intervention or were computed from the additional resources required using the ingredients approach (Levin \& McEwan, 2001). ${ }^{11}$ Besides the direct costs of the intervention, the cost of 2 additional years of schooling for each added

\section{(footnote continued)}

$3 \%$ ) and because many reforms have shown larger impacts for minorities.

${ }^{11}$ For example, costs of PPP and CPC were taken directly from the studies and converted to 2004 prices (see Table notes). Costing of CSR was based on the need for more teachers and classrooms and for FTF more teachers and counselors. For TSI, we estimated a $10 \%$ increase in salaries and benefits. Both PPP and CPC reduced grade retentions and assignments to special education, thus saving public costs. These cost savings have been deducted to obtain "net" costs of producing additional high school graduates. graduate was calculated, as well as the state college subsidies for those additional graduates who might be expected to pursue higher education. Since these new high school graduates were likely to have lower academic achievement and socioeconomic status than existing graduates, we estimated college continuation and completion rates accordingly. ${ }^{12}$ Thus, the total public cost of raising graduation rates of black males is the sum of the direct program (intervention) costs and the additional publicly funded schooling and college induced by the intervention. To ensure consistent accounting, all money figures are expressed as present values at age

\footnotetext{
${ }^{12}$ We used the NELS88 follow-up of eighth graders to estimate college participation 6 years later. Among black male graduates in the lowest quartile on reading scores, about $18 \%$ and $16 \%$ were in 2-year and 4-year colleges. According to the 1996/01 BPS 5 -year completion rates for the bottom third of socioeconomic status are $50 \%$. Thus, for our calculations, one of twelve of the new high school graduates is expected to complete a 4-year degree and one of six, a 2-year degree.
} 
Table 3

Mean labor market outcomes by educational attainment for black males aged 21-64

\begin{tabular}{llll}
\hline & High school dropout & High school diploma & $\begin{array}{l}\text { High school diploma or } \\
\text { more }\end{array}$ \\
\hline Employed (\%) & & 78.8 & 7.9 \\
Unemployed (\%) & 10.0 & 8.7 & 7.8 \\
Discouraged worker (\%) & 1.3 & 0.9 & 0.6 \\
Not in the labor force-other (\%) & 39.9 & 23.1 & 19.7 \\
No. of weeks worked last year & 25.4 & 35.5 & 38.0 \\
Employer provides pension plan (\%) & 33.1 & 50.7 & 58.0 \\
Covered by employer/union-provided & 23.2 & 42.8 & 48.9 \\
health insurance (\%) & 12,262 & 22,199 & 31,230 \\
Annual earnings (all persons) (\$) & & & \\
\hline
\end{tabular}

Note: Sample includes men aged 21-64. All means are weighted. Data is from March supplement of the Current Population Survey, 2003 and 2004. Annual earnings includes all persons, working or not.

20 with a discount rate of $3.5 \%$ and using 2004 prices. $^{13}$

The end columns of Table 2 show the program costs per student, the program costs per new high school graduate, and the total educational costs per new high school graduate. The program costs per student refer to all students who receive the intervention, but of course many of these would have graduated even in its absence (we assume these persons cannot be identified ex ante). Program costs vary from $\$ 13,100$ to $\$ 2900$. Costs per additional graduate refer to the public costs when divided by only the additional graduates that are produced. These vary from $\$ 34,300$ to $\$ 95,500$. The final column shows the total public cost when educational progression has been accounted for.

Assuming that the intervention is delivered to 100 students whose graduation probabilities are unknown, the total public cost per new high school graduate ranges from $\$ 59,100$ to $\$ 120,200$. The lowest public cost per additional graduate is found for FTF (because it is implemented in high school it is the least affected by adjusting to present value at age 20). Although TSI is associated with the highest cost among these alternatives, we remind the reader that the TSI result is an average for all students, and there are good reasons for expecting that success

\footnotetext{
${ }^{13}$ The choice of the appropriate discount rate is a subject of debate. A discussion of the issues and the choice of $3.5 \%$ is in Moore, Boardman, Vining, Weimer, and Greenberg (2004). Because the interventions occur at different ages and yet could all be implemented immediately (albeit on a different cohort of children), we choose age 20 as the focal year. Costs or benefits before that age are uprated (inflated) by $3.5 \%$ and after that age are discounted by $3.5 \%$.
}

rates might be considerably higher, even double, for black males. Krueger and Whitmore (2001) reevaluated the Tennessee Class Size Reduction data; they found the gain for blacks was 7-10 percentile points (versus 3-4 percentile points for whites) and that during the years of class size reduction, $\mathrm{K}-3$, the test score gap between blacks and whites declined by $38 \%$ and by about $15 \%$ thereafter. If a similar doubling of the average effect were to result from higher salaries for teachers, the TSI cost per additional graduate would fall to among the lowest.

\section{Public benefits of additional black male graduates}

Additional black male high school graduates not only have better life chances for themselves, but they also provide public benefits via government savings. Here, we briefly review the methods for deriving these public benefits and we calculate the effects per graduate (for full details, see Belfield (2006); Muennig (2006); Rouse (2006)).

\subsection{Additional tax revenues}

Table 3 shows the labor market outcomes by educational attainment for black males aged 21-64 (CPS data, see Rouse, 2006). Strikingly, black male high school dropouts are less likely to participate in the labor force or be employed (or work continuously). Across all black males (regardless of employment status), dropouts report considerably lower earnings than graduates. In addition, graduates are more likely to have health insurance and pension coverage. These differences in labor market status 
translate not only into higher earnings, but also higher tax revenues as a public benefit over the lifetime.

Rouse (2006) follows a three-step procedure to estimate the additional tax revenues per new high school graduate. First, she estimates the age-earnings profiles of black males with different education levels. Data from the 2003 and 2004 CPS are combined to get an adequate sample size of about 11,000 black males aged 21-64. From these data, Rouse estimates the additional lifetime income associated with graduation and higher education (assuming productivity growth of $1.5 \%$ p.a.). Second, she uses the NBER TAXSIM to estimate the federal and state taxes on these incomes. Third, the lifetime figures are converted to present values at age 20 , using a $3.5 \%$ discount rate.

This method is likely to produce conservative results. Although earlier economic literature assumed that the measured returns to schooling or the schooling coefficient in earnings functions was overstated because of unmeasured differences in ability associated with the schooling variable, a variety of more recent studies do not confirm that expectation. Studies of twins and siblings with different levels of education as well as those using instrumental variables have found that the "naïve" coefficient in earnings functions does not appear to be biased upward. ${ }^{14}$ Accordingly, no adjustment is made for differential ability in these estimates. Importantly, CPS data include "high school equivalency" in their definitions of education, meaning those who passed the GED exam-about 14\% of all black males - are treated as high school graduates. ${ }^{15}$ Yet, although the GED is popularly referred to as a "high school equivalency", it is not; GED recipients' earnings profiles are closer to those of dropouts than to high school graduates (Cameron \& Heckman, 1993). Thus, the differential earnings associated with high school completion is understated in CPS data since the presence of GED recipients biases downward the additional income that is associated with actual high school completion.

\footnotetext{
${ }^{14}$ See the review in Rouse (2006). Levin (1972) assumed a $25 \%$ downward adjustment in additional earnings for an ability correction.

${ }^{15}$ The CPS does not adjust for the probability of incarceration. At age 20 , about $19 \%$ of black male high school dropouts are incarcerated; for black male high school graduates, the percentage declines to $8 \%$. All income and tax revenue estimates take this into account.
}

This method yields significant differences in earnings and tax contributions across education levels. Whereas the present value lifetime earnings of black male dropouts are $\$ 292,200$ at age 20 , the respective figures are $\$ 601,800$ for high school graduates and $\$ 1,479,000$ for those with a B.A. degree or above. There are correspondingly large differences in tax payments. A black male dropout contributes $\$ 118,000$ in income taxes over his lifetime; the respective figures are $\$ 222,400$ for high school graduates and $\$ 607,000$ for college graduates. To these, we add property tax and sales taxes, which increase all values by $5 \%$. Overall, the present value at age 20 of the extra tax revenue associated with each additional high school graduate would be about $\$ 167,600 .^{16}$ Therefore, higher tax revenues alone would pay for any of the five interventions.

\subsection{Projected savings in public health costs}

High school graduates have improved health status, lower rates of mortality, and fewer social problems (Lantz et al., 1998). This is true for blacks and whites, but the lower educational levels of black males contributes to less healthy lifestyles and poorer health status such that their life expectancy is considerably shorter than for white males: Arias, Anderson, Kung, Murphy, and Kochanek (2003, p. 116) report that as of 2001 black male life expectancy was 69 years compared to 75 years for white males, a shockingly large gap.

Because of poorer job prospects and low incomes, black male dropouts are unlikely to have private health care coverage. By default, they must depend upon health care that is publicly or philanthropically financed. The largest insurer for those under age 65, Medicaid, is a means-test program for which eligibility depends upon low income. Participation in Medicaid declines with education because those with more education are more likely to have higher incomes; this makes them ineligible, as well as being more likely to have private health insurance (as shown in Table 3). In addition, those who qualify for Social Security Disability Income (SSDI) receive

\footnotetext{
${ }^{16}$ Sales tax was calculated for each state as per capita tax revenues divided into personal per capita income; a national average was obtained using state population weights. This figure was multiplied by the after-tax difference in incomes between dropouts and graduates (factoring in college progression rates). Sources for these data were: Federation of Tax Administrators; U.S. Department of Commerce; Bureau of Economic Analysis; and the Survey of Current Business.
} 
benefits from Medicare. For example, kidney disease is the most important qualifying condition, a condition for which persons with lower educational attainments are especially at risk (Wong, Shapiro, Boscardin, \& Ettner, 2002). Functional limitations prior to age 65 are also a basis for SSDI benefits, and these are higher for persons with less education (Cutler \& Lleras-Muney, 2006).

The estimates for differences in public costs of health care by educational level are derived from the 2002 Medical Expenditure Panel Survey (MEPS). This is a nationally representative sample of more than 40,000 non-institutionalized civilians with over-sampling of households with incomes less than twice the poverty line. The MEPS data also contains socio-demographic data as well as the medical expenditures (we can also measure health-related quality of life). These estimates were combined with enrollment costs from the National Health Accounts (NHA) to estimate aggregate health expenditures (Arnett et al., 1990).

Two analyzes were performed. First, a regression analysis was used to predict coverage by public insurance with controls for age, race, gender, and ethnicity. Second, per capita public insurance costs were estimated for black males at different educational levels. The latter includes costs not captured in the MEPS such as government payments to hospitals that serve disproportionately low-income populations. ${ }^{17}$ For black males aged $18-24$, the gradients of public coverage are steep: $81 \%$ of those with less than 9 years of education have publicly reimbursed care; but only $28 \%$ of college graduates... Over the lifetime, we estimate the savings in public health costs for each high school graduate relative to dropout at about $\$ 33,500$ in present value terms at age 20 using a $3.5 \%$ discount rate.

\subsection{Projected savings in criminal justice costs}

High school graduates are much less likely to commit crimes than dropouts (Lochner \& Moretti, 2004). With an average rate of institutionalization for all black males $18-65$ at $8 \%$, the rate is $19 \%$ for dropouts, $8 \%$ for graduates, and $1 \%$ for college graduates (Raphael, 2004). For younger cohorts, roughly one-quarter of black male dropouts is incarcerated (Harrison \& Karberg, 2003). Impor-

\footnotetext{
${ }^{17}$ The analysis also calculated health-related quality of life scores for black males which were shown to be positively related to education and negatively related to age.
}

tantly, overall rates of incarceration for black males are six to eight times those of white males (Pettit \& Western, 2004).

Belfield (2006) divides the economic burden of crime for the public sector into four categories: criminal justice system operation (police, courts); costs of incarceration including parole and probation; public restitution to victims; and crime prevention expenditures by government agencies. He examines the relationship between graduation and five types of crime: murder; rape/sexual assault; violent crime (robbery, aggravated assault); property crime (burglary, larceny); and drug offenses. Each of these crime types imposes high public costs and is lower for those with more education. The effect of education on the commission of these crimes is based on results from Lochner and Moretti (2004). Unit costs are estimated from a range of sources, including Bureau of Justice Statistics and the FBI Uniform Crime Rate data. Over the lifetime, the minimum public costs of criminal justice that would be saved by converting a high school dropout to a graduate would be at least $\$ 55,500 .^{18}$

\section{Public investment returns}

When we add up the three public benefits to education, they are substantial. Specifically, the value of just the public benefits embodied in additional tax revenues and reductions in the cost of public health and crime amounts to almost $\$ 256,700$ per new high school graduates. Yet, these public benefits of investment in better education must be weighed against the public costs to ascertain the returns to the investment. Table 4 shows the net present values of the lifetime public benefits of graduation for black males for each of the five potential interventions. The savings are reported in the top panel, with the total costs for each of the five interventions reported just below. The benefit/cost ratio ranges from about two to greater than four among the alternatives meaning

\footnotetext{
${ }^{18}$ This estimate is understated for two reasons and should be viewed as highly conservative because the five specific types of crime listed here account for, perhaps, $80 \%$ of the differential costs associated with education. Detailed data on the public costs associated with other crimes is not readily available. Also, the costs of juvenile crime before the age of 20 are not included. Thus, we believe that the public benefit in reducing the costs of criminal justice through raising educational attainments is even higher than this estimate and should be interpreted in that light.
} 
Table 4

Estimated public net benefits per black male high school graduate

\begin{tabular}{|c|c|c|c|c|c|}
\hline \multirow[b]{2}{*}{ Tax revenues $(\$)$} & \multicolumn{5}{|c|}{ Present values at age 20 per new high school graduate (discount rate of $3.5 \%$ ) } \\
\hline & 167,623 & & & & \\
\hline Health cost savings $(\$)$ & 33,518 & & & & \\
\hline Crime cost savings $(\$)$ & 55,524 & & & & \\
\hline \multirow[t]{2}{*}{ Total benefits $(\$)$} & 256,665 & & & & \\
\hline & FTF & $\mathrm{CPC}$ & PPP & CSR & TSI \\
\hline Total costs $(\$)$ & 59,066 & 67,714 & 90,694 & 97,373 & 120,238 \\
\hline Benefit/cost ratio & 4.35 & 3.79 & 2.83 & 2.64 & 2.13 \\
\hline Net present value $(\$)$ & 197,599 & 188,951 & 165,971 & 159,292 & 136,427 \\
\hline $\begin{array}{l}\text { Total economic effect of equal graduation } \\
\text { rates for black and white males (in } \$ \text { billion) }\end{array}$ & 4.74 & 4.53 & 3.98 & 3.82 & 3.27 \\
\hline
\end{tabular}

that for every dollar invested in raising high school completion among this group, there are two to four dollars in public benefits. Even more impressive is the large surplus of benefits over costs for each additional graduate. For each additional black male high school graduate, the net public benefit in present value at age 20 is between $\$ 136,400$ and $\$ 197,600$. Taking the median intervention, the net present value is $\$ 166,000$, which is over 10 times the cost of delivering the intervention to one single student. To give an aggregate picture of the potential for reaping public benefits of educational improvements for black males, we report the net savings from simply equalizing the graduation rates of black and white males for a single cohort of 20 -year olds. The net public benefit would range from $\$ 3.27$ billion to $\$ 4.74$ billion, with a median figure of $\$ 3.98$ billion.

Given our research method, these results are probably understatements of the total public savings. They do not include public assistance, a full accounting of the criminal justice costs, intra-family benefits, or the deadweight loss of taxation. ${ }^{19}$ They assume that interventions cannot be reasonably targeted to youth on the margin of graduation, but must be given to all. One source of underestimation is that there are a number of newer, promising interventions. These may have even more powerful effects as they reflect a convergence of agreement on

\footnotetext{
${ }^{19}$ Costs of public assistance are difficult to calculate because they are mainly embodied in the TANF program which provides support for children in low-income families. But, most of this funding goes to single mothers, even though fathers' behavior is clearly influential.
}

what is needed to ensure graduation: small school size, high levels of personalization, high academic expectations, strong counseling, parental engagement, extended-time school sessions, and competent and appropriate personnel. ${ }^{20}$ However, they have not been rigorously evaluated yet.

This is a case where greater equity produces greater efficiency in the use of public resources. Yet, these high public returns also pose a quandary for financing these educational improvements. Over half the public benefits accrue to the federal government, but it pays less than $10 \%$ of the cost of $\mathrm{K}-12$ schooling. Thus, the incentive structure for reaping the benefits is not well-aligned with the tax system.

Crucially, our estimates completely ignore the private consequences to the individuals themselves and the social costs to families and local communities. Among all the sub-populations, black males face the biggest challenge. Not only do they trail others in educational opportunities and outcomes in youth, but economic prospects in adulthood are not

\footnotetext{
${ }^{20}$ Small size describes a small school in which students and staff are known to each other and accountable. Personalization refers to a caring environment in which individual personal and academic needs are addressed. High academic expectations call for a demanding level of study that each student is expected to meet. Strong counseling refers to the availability of personnel to guide students facing personal challenges. Parental engagement enlists parents in support of the educational accomplishments of their child and the school. Extended time refers to longer time in school. Competent and appropriate personnel refer not only to teaching qualifications of personnel, but also to their commitment to the school. These changes should not be done on an individual basis but together to comprise a different schooling experience (Quint, 2006).
} 
promising. Despite the nation's strong economic growth in the 1990s, black male adults did see lower rates of unemployment, but they also experienced lower employment and labor force participation rates and significantly higher incarceration rates (Holzer \& Offner, 2006). Other than education, there is a dearth of solutions to this situation; those that are offered tend to be reactive, such as making sure ex-offenders get job training programs, rather than proactive changes that would avoid involvement in the criminal justice system in the first place (Pouncy, 2006). Given the estimates derived here, showing underinvestment and high returns, it makes economic sense to consider effective educational investments in black male high school dropouts as a high priority.

\section{Acknowledgments}

The authors thank Benoît Millot, two anonymous reviewers, and participants at the Conference "Economics of Education: Major Contributions and Future Directions" in honor of Jean-Claude Eicher, Dijon, France, June 2006.

\section{References}

Arias, E., Anderson, R., Kung, H., Murphy, S., \& Kochanek, K. (2003). Deaths: Final data for 2001. National Vital Statistics Reports, 52.

Arnett, R. H., Blank, L. A., Brown, A. P., Cowan, C. A., et al. (1990). Revisions to the national health accounts and methodology. Health Care Finance Review, 11, 42-54.

Belfield, C. R. (2006). The consequences of raising the graduation rate for black males: The effects on crime. Working paper, Teachers College, New York.

Belfield, C. R., Nores, M., Barnett, S. W., \& Schweinhart, L. J. (2006). The high/scope Perry Preschool Program. The Journal of Human Resources, 41(1), 162-190.

Cameron, S. V., \& Heckman, J. J. (1993). The nonequivalence of high school equivalents. Journal of Labor Economics, 11(1), $1-47$.

Cutler, D., \& Lleras-Muney, A. (2006). Education and health. Presented at the health effects of non-health policy conference. Bethesda, MD.

Duncombe, W., \& Yinger, J. (2005). How much more does a disadvantaged student cost? Economics of Education Review, 24, 513-532.

Education Trust. (2006). The funding gap 2005: Low income and minority students short-changed by most states. Washington, DC: The Education Trust.

Finn, J. D., Gerber, S. B., \& Boyd-Zaharias, J. (2005). Small classes in the early grades, academic achievement, and graduating from high school. Journal of Educational Psychology, 97, 214-223.
Harrison, P. M., \& Karberg, J. (2003). Prison and jail inmates at midyear 2002. Bureau of Justice Statistics Bulletin, NCJ 198877. Washington, DC: US Department of Justice.

Holzer, H. J., \& Offner, P. (2006). Trends in employment outcomes of young black men, 1970-2000. In R. B. Mincy (Ed.), Black males left behind (pp. 11-38). Washington, DC: Urban Institute.

Holzman, M. (2006). Public education and black male students: The state report card. 〈http://www.schottfoundation.org $\rangle$.

Jencks, C., \& Phillips, M. (1998). The black-white test gap. Washington, DC: Brookings Institution Press.

Krueger, A. B., \& Whitmore, D. M. (2001). Would smaller classes help close the black-white achievement gap? Working paper \# 451, Princeton University.

Lantz, P. M., House, J. S., Lepkowski, J. M., Williams, D. R., Mero, R. P., \& Chen, J. (1998). Socioeconomic factors, health behaviors, and mortality: Results from a nationally representative prospective study of US adults. Journal of the American Medical Association, 279, 1703-1708.

Levin, H. M. (1972). The cost to the nation of inadequate education. In Proceedings of the select senate committee on equal educational opportunity, 92nd congress. Washington, DC: US Government Printing Office.

Levin, H. M., \& McEwan, P. J. (2001). Cost-effectiveness analysis: Methods and applications. Thousand Oaks, CA: Sage Publications.

Lochner, L., \& Moretti, E. (2004). The effect of education on crime: Evidence from prison inmates, arrests, and self-reports. American Economic Review, 94, 155-189.

Loeb, S., \& Page, M. E. (2000). Examining the link between teacher wages and student outcomes: The importance of alternative labor market opportunities and non-pecuniary variation. The Review of Economics and Statistics, 82, 393-408

Moore, M. A., Boardman, A. E., Vining, A. R., Weimer, D. L., \& Greenberg, D. H. (2004). Just give me a number! Practical values for the social discount rate. Journal of Policy Analysis and Management, 23, 789-812.

Muennig, P. (2006). The consequences of inadequate education for black males: The effects on health. Working paper, Teachers College Equity Symposium.

NCES. (2005). Digest of educational statistics. Washington, DC: NCES

Neal, D. (2006). Why has black-white skill convergence stopped? In E. Hanushek, \& F. Welch (Eds.), Handbook of the economics of education. New York: Elsevier.

Peevely, G., Hedges, L., \& Nye, B. A. (2005). The relationship of class size effects and teacher salary. Journal of Education Finance, 31, 101-109.

Pettit, B., \& Western, B. (2004). Mass imprisonment and the life course: Race and class inequality in US incarceration. American Sociological Review, 69, 151-169.

Pouncy, H. (2006). Toward a fruitful policy discourse about less-educated young men. In R. B. Mincy (Ed.), Black males left behind (pp. 293-310). Washington, DC: Urban Institute.

Quint, J. (2006). Meeting five critical challenges of high school reform. New York: Manpower Development Research Corporation.

Quint, J., Bloom, H. S., Rebeck Black, A., Stephens, L., \& Akey, T. M. (2005). The challenge of scaling up educational 
reform: Findings and lessons from First Things First. New York: Manpower Development Research Corporation. Raphael, S. (2004). The socioeconomic status of black males: The increasing importance of incarceration. Working paper, University of California-Berkeley.

Reynolds, A. J., Temple, J. A., Robertson, D. L., \& Mann, E. A. (2002). Age 21 cost-benefit analysis of the Title I Chicago Child-Parent Centers. Educational Evaluation and Policy Analysis, 24, 267-303.
Rouse, C. E. (2006). The economic consequences of inadequate education for black males: The effects on labor market income and tax revenue. Working paper, Teachers College Equity Symposium.

Rumberger, R. (2004). Why students drop out of school. In G. Orfield (Ed.), Dropouts in America. Cambridge, MA: Harvard University Press.

Wong, M. D., Shapiro, M. F., Boscardin, W. J., \& Ettner, S. L. (2002). Contribution of major diseases to disparities in mortality. New England Journal of Medicine, 347, 1585-1592. 